\title{
Hydrocarbon contamination of a typical mangrove floor in Niger Delta, Nigeria
}

\author{
${ }^{*}$ L.C. Osuji and P. E. Ezebuiro
}

Petroleum and Environmental Chemistry Research Group, Department of Industrial and Pure Chemistry, University of Port Harcourt, PMB 5323, Choba Port Harcourt, Nigeria

Received 11 November 2005; revised 29 May 2006; accepted 8 June 2006; available online 25 June 2006

\begin{abstract}
The impact of petroleum hydrocarbons on the floor of a mangrove system located on one of the intertidal lands behind the barrier islands of Niger Delta basin of southern Nigeria was evaluated following the Obiafu14 oil spillage. The area covered by the oil spill was delimited by reconnaissance and soils were sampled by grid method from the bottom and middle slopes of oil-affected and unaffected (control) sites. Soil samples were later brought to the laboratory where total hydrocarbon content was determined by extraction and spectrophotometric techniques. A lower $\mathrm{pH}$ range of 4.28-4.36 in the oil impacted soils meant that the site was more acidic; a higher moisture content of $33.34 \%$ and lower electrical conductivity (EC) of $31.75 \mu \mathrm{S} / \mathrm{cm}$ in the affected area presupposed oxygen deprivation and lower salt content respectively. On the strength of the baseline data on the study area and evidence from the uncontaminated, geographically similar control site, it can be said that the Obiafu- 14 oil spillage had severely contaminated the affected mangrove floor. This is corroborated by a total extractable hydrocarbon content of $6.32 \times 10^{3} \pm 344 \mathrm{mg} / \mathrm{kg}$ (no overlap in Standard Error at 95\% Confidence Limit), and the abysmal degradation of the mangrove system at the site. Although soils of the mangrove floor under consideration may well be of limited cultivation value on account of the people's dual occupation in fishing and farming, the presence of such levels of petroleum hydrocarbons at the study site might hamper agricultural productivity.
\end{abstract}

Key words: Mangrove floor, petroleum hydrocarbons, oil spill, NigerDelta

\section{INTRODUCTION}

The recovery of petroleum hydrocarbons from oil and gas producing formations has not been without its attendant environmental consequences. In Nigeria, over $90 \%$ of the activities take place onshore, near shore and offshore of the Niger Delta and currently in offshore continental shelf and in all of these, the impacts from onshore activities are known to be greater (NDES, 1999). The most contentious and recalcitrant of these activities is oil spillage, which in most cases have typically affected the mangrove ecosystem. In environments that are completely aquatic, oil sometimes floats on water surfaces, where it is dispersed to shorelines by wind and wave actions, invariably affecting the mangrove floor. The mangrove ecosystem of the Niger Delta occupies intertidal land in a broad zone of tidal creek behind the barrier islands. This is different from what obtains in some other regions, where mangrove forests occur only as a thin band along the coast and are exposed directly to seawater. The mangrove floor is important to

*Corresponding author, Email: osujileo@yahoo.com Tel.:+234803 3409338; Fax:+234803 3409338 innumerable smaller flora and fauna, and so ultimately the food chain leading to man. Many invertebrate species such as crabs and certain shrimps live hidden in burrows. The firm ground of the mangrove floor consists of peat formed by accumulated rootlets of Rhizophora (Odum, 1971). One of the methods of knowing whether an area is contaminated or polluted is by estimating the total extractable hydrocarbon content of the impacted soil. Records of hydrocarbon content seasonally taken shall enhance our ability to confirm the extent of contamination and/or pollution, especially by comparing with data from virgin areas or available baseline data from regulatory bodies. Empirical records of the hydrocarbon content are therefore of great monitoring importance whether or not there is evidence of oil seepage from field reconnaissance. Whereas the effects of oil on the mangrove environment is well known and a large number of studies appear to have been carried out in the Niger Delta, available information is still not sufficient to assess the present condition of the region with respect to oil spills (Indonesia No. 41, 1999). Studies have shown that 
just as the nature of the hydrocarbon fluid produced is peculiar to its environment of recovery, so also is its impact specific on any affected site (Indonesia No. 41, 1999; Osuji et al., 2004 and Osuji and Onojake, 2004). For instance, in an environment that is completely terrestrial, the penetration and spread of oil in the soil will depend on the nature and topography of the soil environment. However, adverse effects of the oil on soil biota will still depend on the degree or extent of hydrocarbon contamination. Therefore the periodic monitoring and analyses of typical and potential pollutants are essential for effective management of the impacted environment. It is for these reasons that we set to empirically quantify the hydrocarbon content and physicochemical characteristics of the Obiafu-14 oil spillage site to ascertain the degree of contamination of the affected mangrove floor.

\section{MATERIALS AND METHODS}

Description of study site, oil spill and date of incidence

The study site is located at Obiafu in the eastern Niger Delta region of southern Nigeria. The site is a mangrove ecosystem (Fig. 1) with exposed crude oil pipelines criss-crossing the right-of-way. The site is sandwiched between Ebocha and Ebegoro oil fields in Obiafu-obrikom community, where the Nigerian Agip Oil Company (NAOC) gas recycling plant is cited (Fig. 2). An adjacently located control area did not have any history of pollution, prior to sampling. The Obiafu-14 oil spillage occurred on the $22^{\text {nd }}$ of March 2003, spilling an estimated 22,000 barrels (approximately 3.5 million litres) of crude oil. The spillage covered an estimated area of approximately five thousand two hundred square metres $\left(5,200 \mathrm{~m}^{2}\right)$.

Table 1: Some baseline characteristics of soils in Obiafu in Niger Delta, Nigeria (Odu et al., 1985)

\begin{tabular}{lcc}
\hline \multicolumn{1}{c}{ Parameters } & Depth $(\mathrm{cm})$ & Concentrations \\
\hline \multirow{2}{*}{$\mathrm{THC}(\mathrm{mg} / \mathrm{kg})$} & $0-15$ & $\mathrm{~N} / \mathrm{D}$ \\
& $15-30$ & $\mathrm{~N} / \mathrm{D}$ \\
$\mathrm{pH}\left(\mathrm{H}_{2} \mathrm{O}\right)$ & $0-15$ & $5.1-6.1$ \\
$\mathrm{EC}(\mu \mathrm{S} / \mathrm{cm})$ & $15-30$ & $5.1-6.1$ \\
& $0-15$ & $10-20$ \\
$\mathrm{Na}^{+}(\mathrm{meq} / 100 \mathrm{~g}$ soil $)$ & $15-30$ & $10-20$ \\
& $0-15$ & $0.20-0.34$ \\
$\mathrm{~K}^{+}(\mathrm{meq} / 100 \mathrm{~g}$ soil) & $15-30$ & $0.19-0.36$ \\
& $0-15$ & $0.10-0.31$ \\
\end{tabular}

Geo-characteristic and climatic disposition of soils

The soils in the Obiafu area were derived from the Upper Cretaceous times onwards. It is called the riverine floodplain where fluviatile sedimentation is sole agent of land formation. Within this river plain, the Niger River occupies a single channel forming the floodplain. Physically, the soils in this area vary from fine textured soils with high silt and clay contents to peaty soils mainly in the mangrove zone. The site lies dominantly in the wet equatorial climatic region, with high cloud cover. Sunshine hr. are low and air is damp for most of the year because of the very high relative humidity of the air. Temperatures are moderated by the cloud cover and by the generally damp air. Still, mean annual temperatures are as high as $25-31^{\circ} \mathrm{C}$. Rain falls every month of the year with a short dry spell in the months of January to March. By and large, the site is in a poorly drained mangrove environment and this poor ground drainage encourages the accumulation of raw organic matter (litter from the mangrove trees) on the soil surface, which decay to form peat. The soil types of the study site mainly cover, middle slope and bottom slope soils (Fig. 2). The general topography of the study area is similar to that of Ebocha reported in Odu et al (1985) and Osuji and Onojake (2004).

Baseline Physico-chemical characteristics of soils Baseline data on hydrocarbon content and some physico-chemical characteristics of soils in the Obiafu study area reported by Odu et al., (1985) has been summarized in Table 1 . The soils are moderately to slightly acidic or neutral in reaction. The soils have low salt content and varying cation exchange capacity.

\section{Vegetation and land use}

In a baseline survey of Obiafu/Obrikom, Odu et al. (1985) reported the floristic composition of the study area. The composition of species is highly heterogenous. Apart from the characteristic Rhizophora spp, there are many other species varying in their frequencies of occurrence. The commonest examples of these are given in Table 1.

Table 2: Commonest species of Obiafu prospect area and their frequencies of occurrence (Odu et al., 1985)

\begin{tabular}{lclc}
\hline \multicolumn{1}{c}{ Species } & \% F & \multicolumn{1}{c}{ Species } & \% F \\
\hline Antidesma spp. & 60 & Cuvaria spp & 43 \\
Paullina pinnata & 59 & Dryopteris spp & 43 \\
Ouratea spp & 57 & Memecylon blackiodes & 38 \\
Elaeis guineensis & 52 & Agelaea oblique & 25 \\
Chassalia spp & 50 & Psychotria manii & 24 \\
\hline
\end{tabular}


Table 3: Total extractable hydrocarbon content and some physico-chemical characteristics of Obiafu-14 oil affected and unaffected site

\begin{tabular}{lccc}
\hline \multirow{2}{*}{ Parameters } & Depth $(\mathrm{cm})$ & \multicolumn{2}{c}{ Concentrations \pm SE at 95\% CL } \\
& & Oil-Affected Site & $\begin{array}{c}\text { Unaffected (Control) } \\
\text { Site }\end{array}$ \\
\hline \multirow{2}{*}{ THC $(\mathrm{mg} / \mathrm{kg})$} & $0-15$ & $6,320 \pm 344$ & $0.02 \pm 0.01$ \\
& $15-30$ & $5,410 \pm 282$ & $0.01 \pm 0.00$ \\
$\mathrm{pH}\left(\mathrm{H}_{2} \mathrm{O}\right)$ & $0-15$ & $4.28 \pm 0.25$ & $5.40 \pm 0.23$ \\
& $15-30$ & $4.36 \pm 0.21$ & $5.54 \pm 0.33$ \\
$\mathrm{EC}(\mu \mathrm{S} / \mathrm{cm})$ & $0-15$ & $31.75 \pm 5.78$ & $37.80 \pm 4.22$ \\
\multirow{2}{*}{ Moisture Content $(\%)$} & $15-30$ & $28.85 \pm 5.36$ & $38.80 \pm 4.15$ \\
& $0-15$ & $33.36 \pm 6.57$ & $22.29 \pm 1.32$ \\
\hline
\end{tabular}

THC = total hydrocasrbon content; EC = Electrical Conductivity

$\mathrm{CL}=$ confidence limit

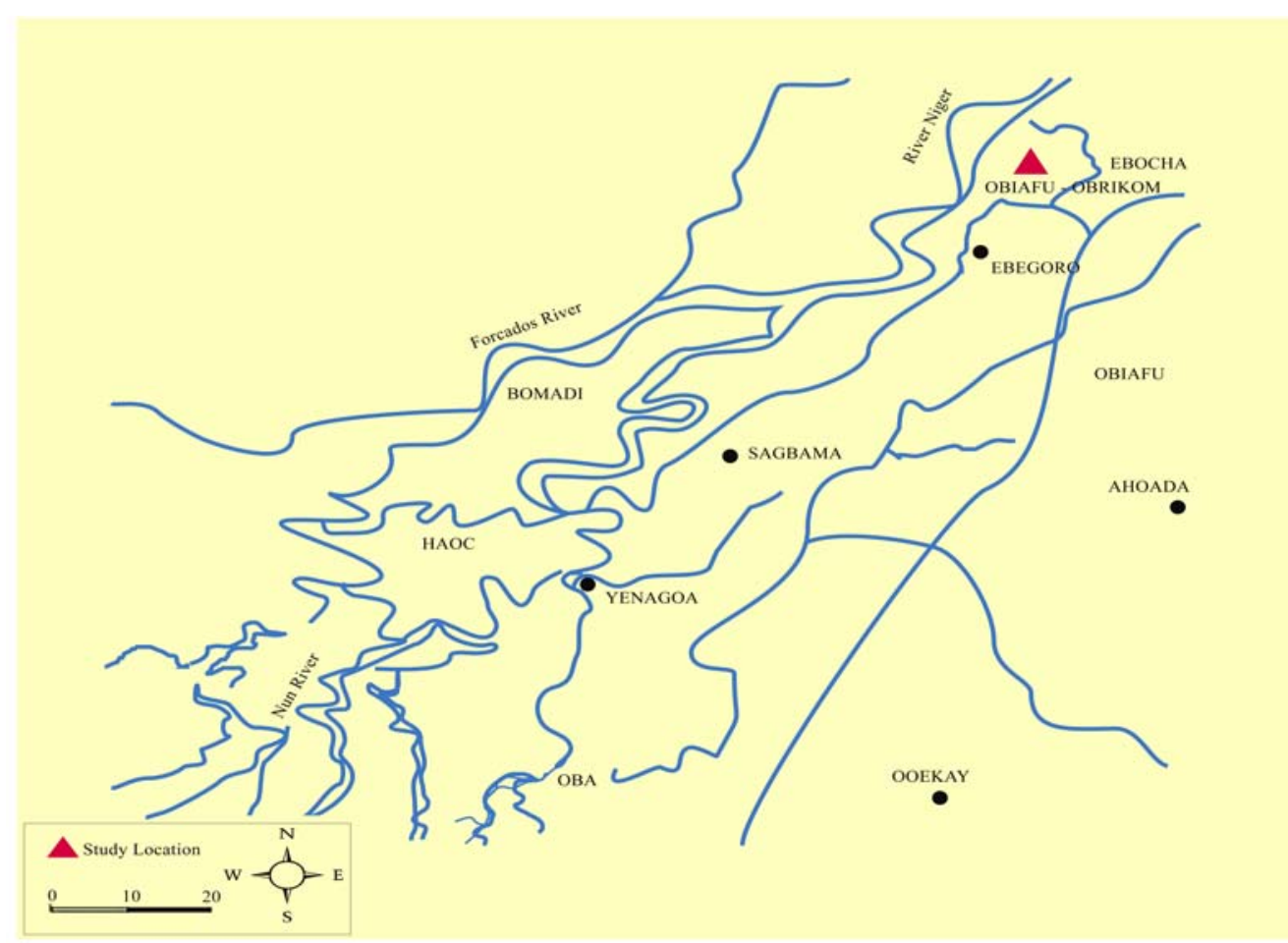

Fig. 1: Map of the Obiafu-14 oil spill study location showing adjoining rivers and creeks of the Niger Delta

Oil extraction and estimation of hydrocarbon content

One gram (1 g) of each soil sample was put into a $500 \mathrm{ml}$ volumetric flask and to this was added $200 \mathrm{ml}$ of xylene. The xylene/soil mixture was shaken vigorously for five minutes and filtered into $400 \mathrm{ml}$ cylinder. The volumetric flask and solid materials were rinsed properly with $500 \mathrm{ml}$ xylene and filtered again into the cylinder. THC in the xylene/hydrocarbon mixture was thereafter determined by photometric method using
Fisher electrophotometer-II at a wavelength of $425 \mathrm{~nm}$. THC was estimated from the calibration curve, obtained by measuring absorbance of a standard prepared by diluting 2.5, 5.0, 10.0, 20.0, 25.0, and 30.0 microlitres of Lease crude oil with $50 \mathrm{ml}$ xylene solution. The absorbance measurement was plotted against the concentration of each calibration standard to obtain the calibration curve. 


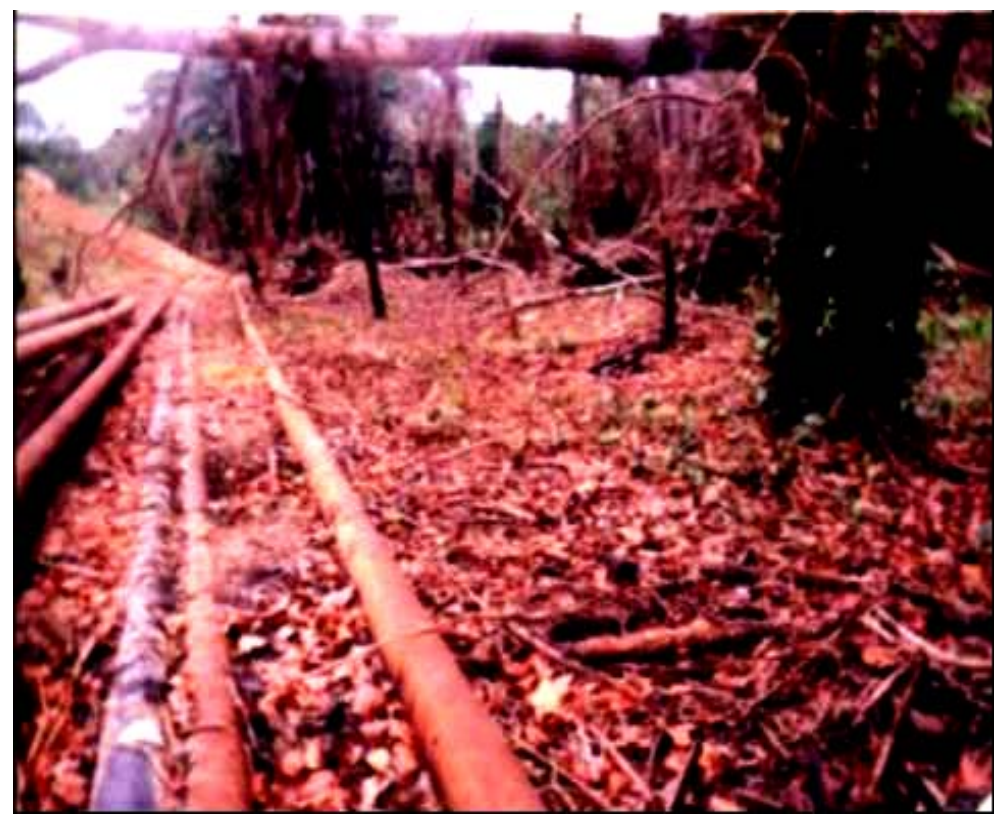

Fig. 2: A section of the study site showing pipelines, mangrove litters and felled tree forms within the right of way

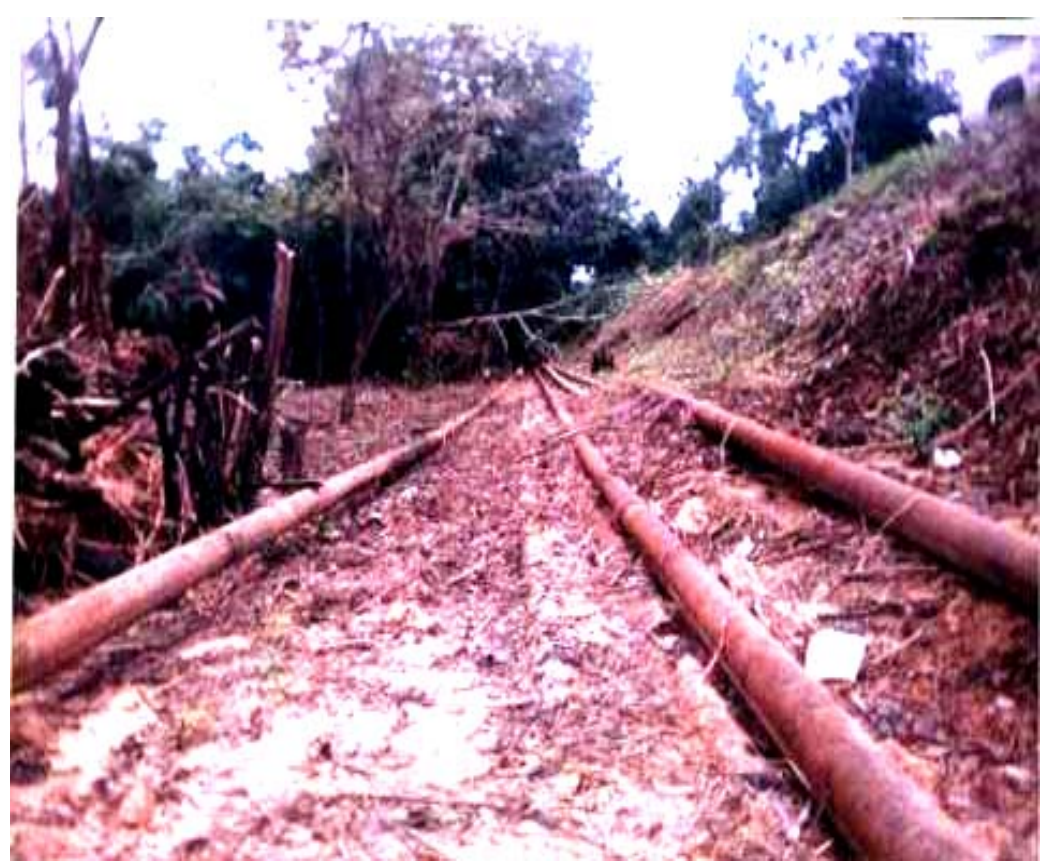

Fig. 3: A section of the study area showing the topography of middle slope and bottom slope soil types with overlying oil pipelines 


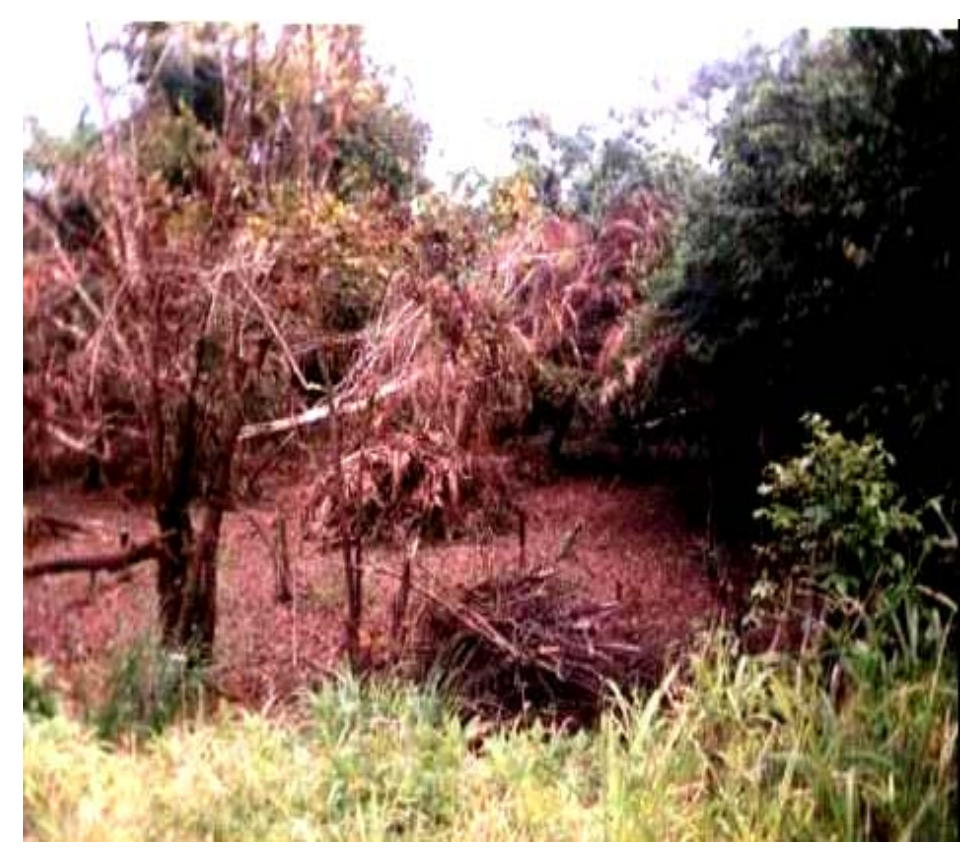

Fig. 4: A close-up view of the oil-affected and unaffected areas showing scanty vegetation, defoliated mangroves and other seeming toxicological and pathological symptoms

$p H$ determination and electrical conductivity

To five grams ( $5.0 \mathrm{~g}$ ) of each soil sample (in a sample cell) was added $50 \mathrm{ml}$ of distilled water. The lump of the soil was stirred to form homogenous slurry, then the pH meter probe (Jenway 3015 model) was immersed into the sample and allowed to stabilize at $25^{\circ} \mathrm{C}$ and pH of sample was recorded. Conductivity was measured using the conductivity meter (Jenway 4010 model).

\section{Determination of moisture content}

A constant weight of watch glass was obtained and thereafter, $20 \mathrm{~g}$ of sample was weighed into the watch glass, and transferred into the oven for $1 \mathrm{hr}$. at $110^{\circ} \mathrm{C}$. The samples were cooled inside a desiccator for 30 minutes before a constant weight of the sample and watch glass after heating and cooling was recorded. Moisture content was estimated as:

$$
\begin{aligned}
& \text { \% Moisture Content }=\left[\mathrm{W}_{1}-\left(\mathrm{W}_{3}-\mathrm{W}_{2}\right] \mathrm{X} 100\right. \\
& \text { Where } \\
& \mathrm{W}_{1}=\text { weight of sample; } \\
& \mathrm{W}_{2}=\text { Constant weight of watch glass; and } \\
& \mathrm{W}_{3}=\text { Weight of sample + watch glass after } \\
& \text { heating and cooling. }
\end{aligned}
$$

\section{RESULTS}

Results for extractable hydrocarbon content and some physico-chemical characteristics of the sampled polluted plots and their unpolluted control are contained in Table 3; the physico-chemical properties measured are $\mathrm{pH}$, electrical conductivity, and percent moisture content. Mean hydrocarbon content of $6.32 \times 10^{3} \mathrm{mg} / \mathrm{kg}$ (no overlap in Standard Error at 95\% Confidence Limit) was obtained for the oil affected site. When compared with soils from the geographically similar reference site, the result was found to be statistically significant $(\mathrm{P}<0.05)$.

\section{DISCUSSION AND CONCLUSION}

The hydrocarbon concentrations obtained in this study presuppose a high level of contamination at the affected site. High hydrocarbon content causes oxygen deprivation and reduction in gaseous diffusion by the surface film of oil and these usually have far reaching implications for the flora and fauna of the affected area, and hence, soil fertility. The presence of oil on the mangrove floor, for instance, will encumber the decay process of the litters from mangroves, which ordinarily enhance the accumulation of organic matter. Osuji et al., (2004) and many past studies on the Niger Delta have reported such higher than normal hydrocarbon 
concentrations in soils many months after oil spillage and have noted similar deteriorations of the mangrove system as a result of such spillages. Aside from the said fertility problems that are usually associated with contamination of the mangrove floor by spilled-oil, oiling of the mangrove system may also be accompanied with many other features such as leaf loss or complete defoliation of the flora from either root or leaf exposure to the oil especially in severely impacted areas; this includes the defoliation of the characteristic Rhizophora mangrove seedlings in affected areas (Ekweozor, 1998). Shriveling, cuppingup of leaves, arrested expansion of buds and some degree of foliar necrosis have also been identified as marked stress signs of a mangrove system plagued with petroleum hydrocarbons (Odu et al., 1985). In a recent field reconnaissance survey, an abysmal decimation of juvenile red mangrove by oil spillage was observed along the Nembe axis of Niger Delta, resulting from either short or long time exposure of the flora to toxic effects of the petroleum hydrocarbons (Obute, 2004). Other species of the mangrove system in the study area that could be adversely affected in the same vein include Paullina pinnata, Antidesma spp, and Ouratea spp, known to have over 50\% frequency of occurrence in this area (cf: Table 1). Where there are no resultant conflagrations, the hydrocarbons accentuated by the spilled-oil are known to hinder root respiration thereby causing death to root cells and loss of mechanical grip. This perhaps explains the defoliated state of some mangroves found at the study site (cf: Figs 2 and 3), especially those that were within the immediate vicinity of the right-of-way. High hydrocarbon content of soils has been known to affect soil physico-chemical properties, which in turn affect the agricultural potentials of such soils (Amadi and Dickson, 1993; Ezebuiro, 2004 and Osuji et al., 2004). Although soils of the mangrove floor under consideration may well be of limited cultivation value on account of the people's dual occupation in fishing and farming, the presence of such levels or range of hydrocarbons at the study site might severe agricultural productivity. In other words, there could be reduced productivity following the impaired state of soil fertility that might result, directly or indirectly, from factors emanating from the presence of petroleum hydrocarbons on site. These factors include (but not limited to) enhanced acidity of the affected surface and subsurface soils, high moisture content and electrical conductivity of the soils. Baseline studies conducted around the study area in 1985 put the $\mathrm{pH}$ range as 5-6 (Amadi and Dickson, 1993). This presupposes that the study area was already on the slightly acidic level before oiling. The degree of acidity or alkalinity of soils is considered a master variable that affects nearly all soil properties. If oiling drops the $\mathrm{pH}$ level below 5 , as is the case herein, the soils would have high concentrations of soluble aluminium and manganese, which would be toxic and ultimately discourage plant growth (Duffus, 1980 and Manahan, 1994). Microbial metabolism might also be hindered in strongly acidic environment, which might reduce the hydrocarbon utilizing capacity of resistant strains of heterotrophic organisms that should be active in degrading the oil (Atlas, 1981; Volkman et al., 1984; Williams et al., 1986 and Odokuma and Okpokwasili, 1994). Thus, the $\mathrm{pH}$ range of 4.28-4.36 obtained in this study (Table 3) may pose some constraints on the remediation or decontamination process of the affected site. The $\mathrm{pH}$ of the affected soils should therefore be raised to desirable levels to enhance metabolic activities and rehabilitation processes on the site; this may done by the application of lime (calcium and magnesium compounds) on soils of the affected mangrove floor. The implications of higher moisture content of 33.34\% (Table 3) are similarly far reaching, especially as regards the availability of oxygen, because high moisture content hinders gaseous diffusion. As the spilled-oil penetrates the sediment column and subsequently binds the sediment and particulate matter of the affected environment, it would increase the stress to both surface and subterranean biota, some of which may eventually die of asphyxiation as a result of oxygen depletion by petroleum hydrocarbons. Electrical conductivity of soils, a measure of the capacity of the soil to conduct or transmit electrical current, is also an indirect measure of ionic concentration in the soil. It is therefore related to dissolved solutes and correlates strongly to soil grain size and texture. In addition to its ability to identify variations in soil texture, it has proven to relate closely to the other soil properties measured herein which determine field productivity. More pointedly, a lower EC of $31.75 \mu \mathrm{S} / \mathrm{cm}$ shows that the salt contents are lower in the oil spill affected site and, therefore, corroborative of the level of contamination on the mangrove floor already established by the amount of hydrocarbons extracted from the site. By and large, the decimation and/or desecration of either 
the mangrove floor or the entire mangrove system are not peculiar to Niger Delta alone. On the international front extensive damage to the mangrove system has likewise been reported over the years and most of these have been attributed to oil spillage. Literature is replete with various accounts of these and their attendant environmental consequences, but perhaps a very common example is the Argea Prima tanker oil spillage of $16^{\text {th. }}$ July 1962 where 10,000 tons of crude oil caused extensive damage to the mangrove floor and, in deed, other features of the entire mangrove swamp habitat on the southern shore of Puerto Rico (Gelder-Ottway, 1976 and Baker, 1976). Various flora and fauna as well as shore dwelling organisms within the vicinity of the oil spill were also contaminated by the expelled petroleum hydrocarbons. In conclusion, the lower $\mathrm{pH}$ range of 4.28-4.36 meant that the site was more acidic while a higher moisture content of $33.34 \%$ and lower electrical conductivity of $31.75 \mu \mathrm{S} / \mathrm{cm}$ in the oil affected site, presuppose that the site was also oxygen deprived and lower in salt content. On the strength of the data provided from baseline studies and the evidence from an uncontaminated geographically similar site, it can be said that the Obiafu-14 oil spillage site was in deed severely contaminated by the oil spillage. These results corroborate the evidence provided by the total extractable hydrocarbon content of $6.32 \times 10^{3} \mathrm{mg} / \mathrm{kg}$ at the oil affected site and the abysmal degradation of the mangrove system observed at field reconnaissance. The $\mathrm{pH}$ may pose some constraints on the remediation or decontamination process of the affected site and should therefore be raised to desirable levels to enhance metabolic activities and rehabilitation process on site; this may done by the application of lime (calcium and magnesium compounds) on soils of the affected mangrove floor. Although soils of the mangrove floor under consideration may well be of limited cultivation value on account of the people's dual occupation in fishing and farming, the presence of such levels or range of hydrocarbons at the study site might impair soil fertility and agricultural productivity.

\section{ACKNOWLEDGEMENTS}

The authors gratefully acknowledge the management of Nigerian Agip Oil Company and the Department of Petroleum Resources at whose instance the field programme for this work was carried out.

\section{REFERENCES}

Amadi, A., Dickson, A. and Maate, G. O., (1993). Remediation of oil polluted soils: Effect of organic and inorganic nutrient supplements on the performance of maize (Zea may L.). Water air soil pollut., 66, 59-76.

Atlas, R. M. (1981). Microbial degradation of petroleum hydrocarbons: an environmental perspective. Microbial Rev., 45 (1), 180-209.

Baker, J. M., (1976). Marine Ecology and Oil Pollution. Applied Science Publishers Ltd., Essex England, 483-536.

Duffus, J. H., (1980). Environmental Toxicology. Edward Arnold Publishers Limited, London. 21-103.

Ezebuiro, P. E., (2004). A review of effect of oil pollution in West Affrican environment. J. Dis. environ. 1 (3), 62-68.

Gelder-Ottway, S. V. and Knight, M., (1976). A review of world oil spillages 1960-1975. In: Baker, J. M., (Ed.), Marine Ecology and Oil Pollution. Applied Science Publishers, Essex, England. 483-520

Manahan, S. E., (1994). Environmental chemistry. CRC Press, Inc. Florida. 811.

NDES, (1999). The Niger delta environmental survey phase 1 report, Environmental and socio economic characteristics. Technical report submitted by Environmental Resource Managers Ltd., Lagos, 1, 22-34.

Odokuma, L. O. and Okpokwasili, G. C., (1994). Seasonal ecology of hydrocarbon utilizing microbes in the surface waters of a river. Environ. Monit. Assess. 27, 175-191.

Odu, C. T. I., Nwoboshi, L. C. and Esuroso, O. F., (1985). Environmental studies soils and vegetation of the Nigerian Agip Oil Company operation areas. In Proceedings of an International Seminar on the Petroleum Industry and the Nigerian Environment. NNPC, Lagos, Nigeria. 274-283.

Odum, E. P., (1971). Fundamentals of ecology. W. B. Saunders Company, Philadelphia. 574.

Osuji, L. C., Adesiyan, S. O. and Obute, G. C., (2004). Post impact assessment of oil pollution in Agbada west plain of Niger Delta, Nigeria: Field reconnaissance and total extractable hydrocarbon content. Chem. Biodivers., 1, 15691577

Volkman, J. K., Alexander, R., Kagi, R. I., Rowland, S. J. and Sheppard, P. N., (1984). Biodegradation of aromatic hydrocarbons in crude oils from the Barrow Sub-basin of Western Australia. Org. Geochem., 6, 619-632.

Williams, J. A., Bjorov, M., Dolcater, D. L. and Winters, J. C., (1986). Biodegradation in South Texas Eocene oils effects on aromatics and biomarkers. Org. Geochem., 10, 451461 . 


\section{AUTHOR(S) BIOSKETCHES}

Osuji, L. C., Ph.D., is a senior lecturer in petroleum and environmental chemistry, Department of Pure and Industrial Chemistry, University of Port Harcourt, Port Harcourt, Nigeria.

Email:osujileo@yahoo.com

Ezebuiro, P. E., M.Sc. degree in Petroleum Chemistry, from the University of Port Harcourt Nigeria. His research interest is in oil pollution studies, Port Harcourt, Nigeria.

\section{This article should be referenced as follows:}

Osuji, L. C., and Ezebuiro, P. E., (2006). Hydrocarbon contamination of a typical Mangrove

floor in Niger Delta, Nigeria. Int. J. Environ. Sci. Tech., 3 (3), 313-320. 